\title{
Sodium-potassium-ATPase activity in the dorsal root ganglia of rats with streptozotocin-induced diabetes
}

\author{
R.J.Green ${ }^{1}$, R. H.M. King' 2 , P. K. Thomas ${ }^{2}$ and D. N. Baron ${ }^{1}$ \\ Departments of ${ }^{1}$ Chemical Pathology and ${ }^{2}$ Neurological Science, Royal Free Hospital School of Medicine, London, UK
}

\begin{abstract}
Summary. Sodium-potassium-ATPase activity was measured in excised dorsal root ganglia of streptozotocin-diabetic rats, 2 months after induction of diabetes. In comparison with agematched controls, there was a decrease in both the total and ouabain-insensitive activity, indicating an overall reduction in ouabain-sensitive activity of $46 \%$. This decrease may explain
\end{abstract}

the reduced amino-acid uptake exhibited by diabetic sensory ganglia and could be relevant to the development of diabetic neuropathy.

Key words: Sodium-potassium-ATPase, dorsal root ganglia, streptozotocin diabetes, diabetic neuropathy.
Most studies on peripheral nerve function in streptozotocin-induced diabetes have concentrated on the changes in the peripheral nerve trunks. Nerve conduction velocity has been shown to be reduced $[1,2]$ and nerve fibre diameter is slightly but significantly less in diabetic compared with control animals. This reduction may be partly the result of a maturational deficit [3] and partially related to axonal 'dwindling' [4] or shrinkage [5]. Segmental demyelination does not occur in the earlier stages $[6,7]$ but degenerative changes including axonal loss and segmental demyelination have been described after prolonged alloxan diabetes in rats [8]. The transport of structural [9] and other proteins, including the enzyme choline acetyltransferase [10], by the slow transport system, is known to be reduced. There are conflicting reports relating to the fast transport system [11].

The synthesis of structural proteins and enzymes takes place virtually entirely in the neuronal perikarya. The events that occur in dorsal root and autonomic ganglia and in anterior horn cells in diabetes are therefore of interest, but few studies on this topic have been undertaken so far. Sidenius and Jakobsen [12] showed that perikaryal volume is less for anterior horn and dorsal root ganglion cells in early streptozotocin-induced diabetes in comparison with controls. Thomas et al. [13] recently reported that amino-acid uptake by dorsal root ganglia was impaired in streptozotocin diabetes, based upon the uptake of 4-amino $\left[{ }^{3} \mathrm{H}\right]$-butyric acid. The incorporation of $\left[{ }^{3} \mathrm{H}\right]$-leucine into protein was also found to be reduced: this could have been secondary to impaired uptake.
The present study has examined the activity of sodium-potassium activated adenosinetriphosphatase $\left(\mathrm{Na}^{+}, \mathrm{K}^{+}\right.$-ATPase, EC 3.6.1.3) in dorsal root ganglia from streptozotocin-diabetic rats. The activity of this enzyme is known to be impaired in diabetic nerve [14, 15] and if it is also reduced in ganglia, this could provide a mechanism for the diminution in amino-acid uptake.

\section{Materials and methods}

\section{Animal preparation}

Diabetes was induced in mature male Wistar rats (aged 4 months, weight $230-280 \mathrm{~g}$ ) by the intraperitoneal injection of a buffered solution of streptozotocin $(55 \mathrm{mg} / \mathrm{kg}$ body weight). Control rats were administered an equivalent quantity of physiological saline (150 mmol/1).

Diabetic and control animals were housed separately in plastic metabolic cages and fed on 41 B Oxoid diet (Oxoid, Basingstoke, Hants, UK) with water ad libitum. Both groups were weighed regularly and the diabetic rats checked for glycosuria. Diabetic animals developed glycosuria in excess of $2 \%$ within a few days of the administration of streptozotocin and progressively lost weight. Both groups were maintained for a period of 2 months. When anaesthetized for removal of the dorsal root ganglia, a blood sample was taken from the tail vein and plasma glucose determined on a Beckman Glucose Analyser II (Beckman, Fullerton, California, USA).

\section{Tissue collection}

Under general anaesthesia with intramuscular Hypnorm (Janssen, Crown Chemicals, Lamberhurst, Kent, UK) and ether inhalation, laminectomy was performed and the five caudal pairs of lumbar dorsal root ganglia were excised under an operating microscope (Zeiss, Jena, DDR). At each session the ganglia from one diabetic and one 
control animal were processed. The excised ganglia were immediately frozen on dry ice after removal of any attached pieces of spinal root and washing free of blood with homogenizing solution. The homogenates were prepared by six passes of a borosilicate manual homogenizer (Baird \& Tatlock, Romford, Essex, UK) in $1 \mathrm{ml}$ of a homogenizing solution comprising sucrose $(250 \mathrm{mmol} / 1)$, EDTA (disodium salt; $1 \mathrm{mmol} / \mathrm{l})$ and Tris base $(20 \mathrm{mmol} / \mathrm{l}, \mathrm{pH} 7.4)$ at $25^{\circ} \mathrm{C}$.

\section{Assay of ATPase activity}

Total ATPase activity was determined in duplicate in $800 \mu$ of buffer containing a final concentration of $\mathrm{NaCl}(100 \mathrm{mmol} / \mathrm{l}), \mathrm{KCl}$ (15 mmol/l), ATP (vanadate-free; $5 \mathrm{mmol} / \mathrm{l}), \mathrm{MgCl}_{2}(5 \mathrm{mmol} / \mathrm{l})$, EDTA (disodium salt; $3 \mathrm{mmol} / 1)$ and Tris base $(50 \mathrm{mmol} / 1, \mathrm{pH} 7.2)$ at $25^{\circ} \mathrm{C}$. Ouabain-insensitive activity was determined similarly in duplicate in $800 \mu \mathrm{l}$ of the same buffer, but with equimolar choline chloride instead of $\mathrm{KCl}$, in the presence of $1 \mathrm{mmol} / 1$ ouabain solution. To initiate the reaction, $200 \mu \mathrm{l}$ of the crude homogenate was added to $800 \mu \mathrm{l}$ of buffer, with or without $1 \mathrm{mmol} / 1$ ouabain or an equivalent volume of $150 \mathrm{mmol} / 1$ saline. The samples were incubated at $37^{\circ} \mathrm{C}$ in a shaking water bath for $20 \mathrm{~min}$. The reaction was terminated by the addition of $1 \mathrm{ml}(15 \%, \mathrm{w} / \mathrm{v})$ trichloracetic acid solution and immediately centrifuged at $500 \mathrm{~g}$ for $5 \mathrm{~min}$. Inorganic phosphate $\left(\mathrm{P}_{\mathrm{i}}\right)$ was determined spectrophotometrically by the manual stannous chloridehydrazine method [16]. Protein estimations for each tube were measured according to the method of Lowry et al. [17]. Ouabain-sensitive $\mathrm{Na}^{+}, \mathrm{K}^{+},-\mathrm{ATP}$ ase activity is the difference between total ATPase and ouabain-insensitive activity and is expressed as $\mu \mathrm{mol} \mathrm{P}_{\mathrm{i}}$ released from ATP per g protein per h at $37^{\circ} \mathrm{C}$. All values obtained were the mean of the two estimations.

\section{Statistical analysis}

The comparisons between the results from the diabetic and control animals were made on mean values using Student's t-test for unpaired data. Results are expressed as mean \pm SEM unless otherwise stated.

\section{Results}

Ten pairs of control and diabetic rats were studied when the latter had been diabetic for 2 months. The operations on the pairs were performed in random order. At the time of the terminal studies, the control animals weighed $413-652 \mathrm{~g}$ and the diabetic animals $232-317 \mathrm{~g}$. Approximately half of the diabetic animals had developed cataracts. The plasma glucose levels for the two sets of animals are shown in Table 1.

\section{ATPase activity}

Mean ouabain-sensitive $\mathrm{Na}^{+}, \mathrm{K}^{+}$, -ATPase levels were consistently less in the ganglia from the diabetic compared with the control animals $(499.4 \pm 43.3$ versus $917.6 \pm 45.7 \mu \mathrm{mol} \mathrm{P}_{\mathrm{i}} \cdot \mathrm{g}^{-1}$ protein $\cdot \mathrm{h}^{-1} ; \quad p<0.001$; Table 1, Fig.1). Table 1 also shows that the total and ouabain-insensitive ATPase activity was reduced in the diabetic group. The reduction in ouabain-insensitive ATPase activity amounted to $17 \%$. The results in Table 1 are tabulated in order of increasing weight of test animal. It is evident that in the control group there is a general trend towards higher ATPase activity in the heavier animals which is not apparent in the diabetic group.
Table 1. ATPase activity in rat dorsal root ganglia

\begin{tabular}{|c|c|c|c|c|}
\hline \multirow[t]{2}{*}{ Ganglia } & \multicolumn{3}{|c|}{$\begin{array}{l}\text { ATPase activity } \\
\left(\mu \mathrm{mol} \mathrm{P}_{\mathrm{i}} \cdot \mathrm{g}^{-1} \text { protein } \cdot \mathrm{h}^{-1}\right)\end{array}$} & \multirow{2}{*}{$\begin{array}{l}\text { Plasma } \\
\text { glucose } \\
(\mathrm{mmol} / \mathrm{l})\end{array}$} \\
\hline & $\begin{array}{l}\text { Total } \\
\text { ATPase }\end{array}$ & $\begin{array}{l}\text { Ouabain- } \\
\text { insensitive } \\
\text { ATPase }\end{array}$ & $\begin{array}{l}\text { Ouabain- } \\
\text { sensitive } \\
\text { ATPase }\end{array}$ & \\
\hline \multirow{10}{*}{$\begin{array}{l}\text { Control } \\
\text { ganglia } \\
(n=10)\end{array}$} & 4483 & 3886 & 597 & 13.7 \\
\hline & 6185 & 5420 & 765 & 11.9 \\
\hline & 4634 & 3746 & 888 & 8.8 \\
\hline & 5154 & 4169 & 985 & 11.9 \\
\hline & 6536 & 5632 & 904 & 10.5 \\
\hline & 6075 & 5086 & 989 & 8.4 \\
\hline & 5851 & 4909 & 942 & 8.0 \\
\hline & 6274 & 5274 & 1000 & 13.5 \\
\hline & 5953 & 4961 & 992 & 11.1 \\
\hline & 6123 & 5009 & 1114 & 9.1 \\
\hline \multicolumn{4}{|l|}{ Mean \pm SEM } & $10.7 \pm 0.66$ \\
\hline Diabetic & 4635 & 4095 & 270 & 44.0 \\
\hline ganglia & 4330 & 3833 & 497 & 34.0 \\
\hline \multirow[t]{8}{*}{$(n=10)$} & 3417 & 3021 & 396 & 32.0 \\
\hline & 4811 & 4416 & 396 & 41.5 \\
\hline & 4651 & 4246 & 405 & 32.0 \\
\hline & 3870 & 3263 & 607 & 36.0 \\
\hline & 4874 & 4365 & 509 & 34.0 \\
\hline & 4985 & 4451 & 534 & 42.6 \\
\hline & 4707 & 4014 & 690 & 28.8 \\
\hline & 4988 & 4298 & 690 & 31.0 \\
\hline Mean \pm SEM & & & & $35.6 \pm 1.7$ \\
\hline
\end{tabular}

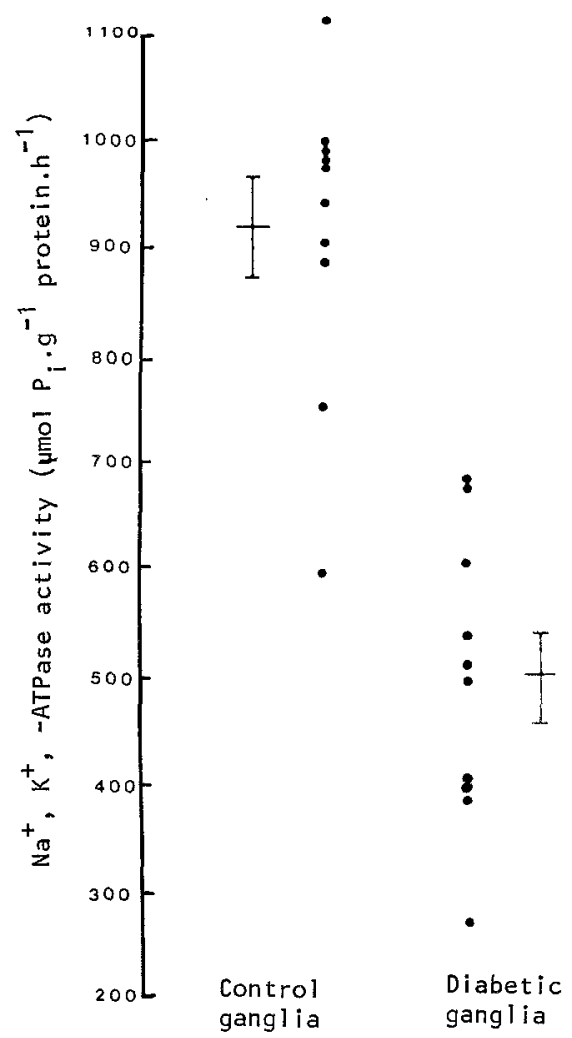

Fig. 1. $\mathrm{Na}^{+}, \mathrm{K}^{+}$,-ATPase activity in dorsal root ganglia of control and streptozotocin-diabetic rats. The bars indicate mean \pm SEM 


\section{Discussion}

The metabolic alterations in diabetic nerve have been clarified to a considerable extent in recent years. The use of endoneurial preparations has established that energy utilization in nerve, like that in brain, is independent of insulin control. It has been shown to be related to exogenous glucose supplies and mainly to be regulated by local energy requirements $[18,19]$. Nevertheless, energy and substrate utilization in resting peripheral nerve is reduced by about $25-30 \%$ in streptozotocindiabetic rats, despite increased tissue concentrations of glucose and fructose [20]. This reduction has been equated with an alteration in nerve $\mathrm{Na}^{+}, \mathrm{K}^{+}$,-ATPase activity: the decrease in steady-state resting energy utilization in diabetic nerve is strictly explicable in terms of a reduction in ouabain-sensitive $\mathrm{Na}^{+}, \mathrm{K}^{+}$,-ATPase activity [21]. The defect in ATPase activity is not affected by insulin in acute experiments in vitro [15]. It is evident that it represents membrane-associated ATPase activity as it is demonstrable in nerve homogenates $[14,15]$ when water-soluble modulators are controlled. The same is true for the present observations.

The defect in $\mathrm{Na}^{+}, \mathrm{K}^{+}$,-ATPase activity has been found to be reversed by correction of the reduced myoinositol concentration known to exist in diabetic nerve [15], possibly through regulation by membrane phosphatidylinositol $[22,23]$. The reduced tissue concentrations of myo-inositol in nerve are likely to be related to competitive inhibition of uptake by glucose on a sodium-dependent carrier mechanism [24]. This carrier mechanism secondarily could be impaired by a reduction in the $\mathrm{Na}^{+}, \mathrm{K}^{+}$,-ATPase activity upon which the mechanism relies. It is relevant in this context that the sodium dependent myo-inositol uptake remains impaired in acute in vitro experiments even if the glucose concentration is normalized [21].

The accumulation of sorbitol in nerve [25] may also impair myo-inositol uptake. Reduction in nerve sorbitol levels by the administration of an aldose reductase inhibitor will increase myo-inositol levels without changes in the degree of hyperglycaemia $[26,10]$.

In relation to the present experiments, it is not yet known whether myo-inositol levels are reduced and sorbitol levels increased in diabetic dorsal root ganglia. If this were so, as in peripheral nerve, it could provide an explanation for the reduced $\mathrm{Na}^{+}, \mathrm{K}^{+}$,-ATPase activity. Amino-acid uptake by cells is dependent on a sodium gradient maintained by $\mathrm{Na}^{+}, \mathrm{K}^{+}$,-ATPase activity [27]. The reduced amino-acid uptake by dorsal root ganglia in streptozotocin-diabetic rats found by Thomas et al. [13] could thus be explained. In its turn, this impaired uptake could have important metabolic consequences, for example through reduced synthesis of structural proteins and enzymes and their reduced delivery to the axons via the axonal transport system. This might constitute a contributory factor in the development of diabetic neuropathy.
The present results have shown that $\mathrm{Na}^{+}, \mathrm{K}^{+},-\mathrm{ATP}$ ase activity in the dorsal root ganglia tends to increase with weight in the control rats (but not in the diabetic animals). Age cannot be directly responsible as the animals were age-matched and initially were all of closely similar weight $(230-280 \mathrm{~g})$. The difference in the final weights of the control animals is presumably the consequence of individual variations in rates of maturation. The present results additionally have indicated that ouabain-insensitive ATPase activity is less in diabetic sensory ganglia, suggesting that the activity of other membrane ATPases is also reduced.

Acknowledgements. We thank Mr. D. Fleming for technical assistance and The British Diabetic Association for financial support. The streptozotocin was kindly supplied by the Drug Development Branch, National Institutes of Health, Bethesda, Maryland, USA.

\section{References}

1. Eliasson SG (1964) Nerve conduction changes in experimental diabetes. J Clin Invest 43: 2353-2358

2. Miyoshi T, Goto I (1973) Serial in vivo determinations of nerve conduction velocity in rat tails. Physiological and pathological changes. Electroenceph Clin Neurophysiol 35: 125-131

3. Sharma AK, Bajada S, Thomas PK (1981) Influence of streptozotocin-induced diabetes on myelinated nerve fibre maturation and on body growth in the rat. Acta Neuropathol (Berl) 53: 257-265

4. Jakobsen J (1976) Axonal dwindling in early experimental diabetes. I. A study of cross-sectioned nerves. Diabetologia 12: 539-546

5. Dyck PJ, Lambert EH, Windebank AJ, Lais AA, Sparks MF, Karnes J, Sherman WR, Hallcher LM, Low P, Service FJ (1981) Acute hyperosmolar hyperglycaemia causes axonal shrinkage and reduced nerve conduction velocity. Exp Neurol 71:507-514

6. Jakobsen $J(1976)$ Axonal dwindling in early experimental diabetes. II. A study of isolated nerve fibres. Diabetologia 12: $547-553$

7. Sharma AK, Thomas PK (1974) Peripheral nerve structure and function in experimental diabetes. J Neurol Sci $23: 1-15$

8. Powell HC, Knox D, Lee S (1977) Alloxan diabetic neuropathy. Electron microscope studies. Neurology (Minneap) 27: 60-66

9. Jakobsen J, Sidenius P (1980) Transport of structural proteins in streptozotocin diabetic rats. J Clin Invest 66:292-297

10. Mayer JH, Tomlinson DR (1983) Prevention of defects of axonal transport and nerve conduction velocity by oral administration of $m y o$-inositol or an aldose reductase inhibitor in streptozotocin-induced diabetes. Diabetologia 25: 433-438

11. Tomlinson DR, Mayer JH (1984) Defects of axonal transport in diabetes mellitus - a possible contribution to the aetiology of diabetic neuropathy. J Auton Pharmacol 4: 59-72

12. Sidenius P, Jakobsen J (1980) Reduced perikaryal volume of lower motor and primary sensory neurons in early experimental diabetes. Diabetes 29: 182-186

13. Thomas PK, Wright DW, Tzebelikos E (1984) Amino acid uptake by dorsal root ganglia from streptozotocin-diabetic rats. J Neurol Neurosurg Psychiatr 47: 912-916

14. Das PK, Bray GM, Aguayo AJ, Rasminsky M (1976) Diminished ouabain-sensitive sodium-potassium ATPase activity in sciatic nerves of rats with streptozotocin-induced diabetes. Exp Neurol 53: $285-288$

15. Greene DA, Lattimer SA (1983) $\mathrm{Na} / \mathrm{K}$ ATPase defect in diabetic rat peripheral nerve: correction by myo-inositol administration. $\mathrm{J}$ Clin Invest 72: 1050-1063

16. Laurence R (1974) Assay of serum inorganic phosphate without deproteinisation: automated and manual micromethods. Ann Clin Biochem 11: 234-237

17. Lowry OH, Rosebrough NJ, Farr AL, Randall J (1951) Protein 
measurement with the folin phenol reagent. J Biol Chem 193: 265-275

18. Greene DA, Winegrad AI (1979) In vitro studies of the substrates for energy production and the effects of insulin on glucose utilization on the neural components of peripheral nerve. Diabetes 28 : 878-887

19. Greene DA, Winegrad AI, Carpentier J-L, Brown MJ, Fukuma M, Orci L (1979) Rabbit sciatic nerve fascicle and endoneurial preparations for 'in vitro' studies of peripheral nerve glucose metabolism. J Neurochem 33: 1007-1018

20. Greene DA, Winegrad AI (1981) Effects of acute experimental diabetes on composite energy metabolism in peripheral nerve axons and Schwann cells. Diabetes 30:967-974

21. Greene DA, Lattimer SA (1983) A self-reinforcing metabolic defect in diabetic peripheral nerve involving myo-inositol and the sodium-potassium ATPase. Clin Res 31:501 A

22. Brown MJ, Greene DA (1984) Diabetic neuropathy: pathophysiology and management. In: Asbury AK, Gilliatt RW (eds) Peripheral nerve disorders. Butterworths, London, pp 126-153

23. Simmons DA, Winegrad AI, Martin DB (1982) Significance of tissue myo-inositol concentrations in metabolic regulation in nerve. Science 217: 848-851

24. Greene DA, Lattimer SA (1982) Sodium and energy-dependent uptake of myo-inositol by rabbit peripheral nerve. Competitive inhibition by glucose and lack of an insulin effect. J Clin Invest 70 : $1009-1018$

25. Gabbay KH, Merola LO, Field RA (1966) Sorbitol pathway: presence in nerve and cord with subacute accumulation in diabetes. Science 151: 209-210

26. Mayer JH, Tomlinson DR (1983) The influence of aldose reductase inhibition and nerve myo-inositol on axonal transport and nerve conduction velocity in rats with experimental diabetes. $J$ Physiol (Lond) 340: 25-36 P

27. Schultz SG, Fuisz RE, Curran PF (1966) Amino acid and sugar transport in rat ilium. J Gen Physiol 49:849-866

Received: 29 May 1984

and in revised form: 16 October 1984

Professor P. K. Thomas

Royal Free Hospital School of Medicine

Rowland Hill Street

London NW3 2PF

UK 